\title{
Kurikulum Tersembunyi Lingkungan di dalam Materi Energi Terbarukan untuk Fisika SMA
}

\author{
Desnita $^{a)}$ \\ Program Studi Pendidikan Fisika, Fakultas MIPA, Universitas Negeri Jakarta, Jakarta, 13220 \\ Email: a)desywaznadil@gmail.com
}

\begin{abstract}
Renewable energy resources education, in essence, is the treatment of various topics and issues related to renewable energy resources and technologies as an environmental hidden curriculum in physics education at Senior High School. Based on the statement, environmental Hidden Curriculum in teaching physics concept, especially renewable energy resource was developed. Used research and development method, with step: need assessment, development theoretic models, validation, trial, and revision. The development result is a curriculum with contain: concept of green energy renewal resource and waste cooking oil as a kind of the resources, producing process, and learning strategies to implementation the curriculum. Implementation as trial this curriculum was conducted at a senior high school in South of Jakarta. Didactic exploration improves the learning process, link or integration in physics concept, when worksheets were used in the physics lab and multimedia system. The worksheet content are picture, video, and text or article about green renewable energy resources. Used project based learning and cooperative learning, using the worksheet was improve not only cognitive aspect of the student, but also their skill and attitude to save environmental.
\end{abstract}

Kata-kata Kunci: environmental hidden curricullum, green renewable energy resources, learning strategies.

\begin{abstract}
Abstrak
Inti dari pendidikan tentang sumber energi terbarukan adalah ujicoba terhadap sejumlah topik dan isu yang terkait dengan sumber energi terbarukan ramah lingkungan dan teknologinya sebagai sebuah kurikulum tersembunyi dalam pendidikan fisika pada tingkat SMA. Berdasarkan alasan tersebut, telah dikembangkan kurikulum lingkungan yang tersembunyi di dalam mengajar konsep fisika, khususnya sumber energi ramah lingkungan. Hasil pengembangan adalah kurikulum yang berisi konsep sumber energi terbarukan ramah lingkungan dan minyak jelanta sebagai salah satu jenisnya, proses produksi, dan strategi pembelajaran dalam penerapan kurikulum tersebut. Implementasi terhadap siswa salah satu SMA di Jakarta Selatan menunjukkan bahwa materi pembelajaran lingkungan dikaitkan atau diajarkan secara terintegrasi dalam pembelajaran fisika, menggunakan lembar kerja yang berisi konsep, gambar, video, dan teks atau artikel tentang sumber energi terbarukan ramah lingkungan di laboratorium multimedia fisika. Menggunakan pembelajaran berbasis projek dan kooperatif, penggunaan lembar kerja tersebut terbukti meningkatkan tidak hanya pengetahuan, tapi juga keterampilan, dan sikap kepedulian siswa terhadap lingkungan.
\end{abstract}

Kata-kata Kunci: kurikulum lingkungan yang tersembunyi, sumber energi terbarukan ramah lingkungan, strategi pembelajaran 


\section{PENDAHULUAN}

Setidaknya ada enam permasalahan lingkungan hidup yang harus diselesaikan, yaitu makanan, air, energi, perubahan iklim, keragaman hayati, dan polusi (Timpakul 2009). Salah satu pemicu masalah tersebut adalah perbuatan manusia. Ulah manusia yang dapat menimbulkan permasalahan lingkungan antara lain: penebangan hutan secara liar, perburuan liar, perusakan hutan bakau, penimbunan rawa-rawa untuk pemukiman, pembuangan sampah di sembarang tempat, bangunan liar di daerah aliran sungai (DAS), pemanfaatan sumber daya alam secara berlebihan di luar batas. Salah satu dampaknya adalah pemanasan global yang berpengaruh terhadap perubahan iklim (http://www.kapanlagi.com/h/0000149403.html).

Dibutuhkan pemahaman, keterampilan, sikap, dan aksi nyata seluruh komponen masyarakat sedini mungkin. Dibutuhkan sinergisitas antarkomponen masyarakat untuk menyelesaikan masalah lingkungan, baik melalui pendidikan formal maupun informal. Payung pendidikan lingkungan untuk pendidikan formal adalah Surat Keputusan (SK) Bersama Menteri Lingkungan Hidup dan Menteri Pendidikan Nasional, No.07/MenLH/06/2005 No.05/VI/KB/2005 untuk pembinaan dan pengembangan pendidikan lingkungan hidup. Di dalam keputusan bersama ini, sangat ditekankan bahwa pendidikan lingkungan hidup dilakukan secara terintegrasi dengan mata pelajaran yang telah ada, (Timpakul 2005).

Salah satu mata pelajaran yang dimaksud dalam SK tersebut adalah Fisika SMA dan salah satu Kompetensi Dasar di dalam kurikulum fisika SMA adalah "Menyajikan ide/ gagasan pemecahan masalah keterbatasan sumber daya energi, energi alternatif, dan dampaknya bagi kehdupan" (Salinan Lampiran Permendikbud, No. 69 Tahun 2013). Kompetensi tersebut tidak mungkin dicapai tanpa mengintegrasikan permasalahan energi sebagai hidden curriculum lingkungan. Muncul beberapa pertanyaan dalam pengintegrasian hidden curriculum lingkungan pada saat mencapai kompetensi dimaksud, yaitu: 1) pengetahuan atau konsep-konsep apa yang dibutuhkan, sehingga dapat memotivasi siswa aktif mencapai kompetensi; 2) keterampilan yang perlu dilatih sebagai pengalaman belajar siswa dalam merancang biodiesel; 3) model, pendekatan, dan strategi pembelajaran yang tepat agar pengalaman belajar memupuk kemampuan siswa menerapkan metode ilmiah dalam menyelesaikan masalah lingkungan; 4) penilaian yang tepat untuk mencapai kompetensi tersebut. Keempat pertanyaan inilah yang dijawab di dalam tulisan ini.

\section{METODE}

Penelitian ini menerapkan metode penelitian pengembangan dengan tahapan: 1) analisis kebutuhan, 2) pengembangan hidden curriculum lingkungan dalam pembelajaran fisika, 3) ujicoba, 4) revisi, dan 5) implementasi.

\section{HASIL PENELITIAN DAN PEMBAHASAN}

Setelah melewati step-step penelitian seperti disampaikan pada metode, didapatkan hasil penelitian berupa sebagai berikut:

\section{Kurikulum}

\section{a) Tujuan pembelajaran}

Berdasarkan hasil analisis kompetensi dasar dan mengacu pada karakter pendidikan lingkungan seperti disampaikan oleh Matarasso, M and Dung, N. V “Environmental Education (EE) is a process aimed at developing a world population that is aware of and concerned about the total environment and its associated problems, and which has the knowledge, attitudes, motivation, commitment, and skills to work individually and collectively toward solutions of current problems and the prevention of new ones" (Matarasso \& Dung 2002) dirumuskan tujuan sebagai berikut: 
TABEL 1. Tujuan Pembelajaran Kurikulum Tersembunyi Lingkungan untuk Fisika SMA

\section{Afektif (Sikap)}

- Menerima informasi tentang krisis energy sebagai permasalahan yang perlu diselesaikan.

- Mencari informasi tentang dampak krisis energy terhadap kehidupan dan lingkungan.

- Mengumpulkan informasi tentang energy alternatif ramah lingkungan.

- Aktif berdiskusi di dalam kelompok kecil untuk merencanakan penelitian pembuatan biodiesel dari bahan baku alami yang terdapat di lingkungan sekitar.

- Berjasama, berbagi tugas, dan saling membantu melakukan penyelidikan pembuatan bahan bakar biodiesel.

- Mempublikasikan hasil penelitian kepada masyarakat di lingkungan.

- Mengajar masyarakat untuk menggali bahan baku biodiesel yang terdapat di dalam lingkungan.

- Mengajak masyarakat menggunakan bahan bakar biodiesel buatan sendiri.

\section{Kognitif (Pengetahuan) $\quad$ Psikomotor (Keterampilan)}

- Membedakan antara • Melakukan eksperimen sumber energy terbarukan dan tidak terbarukan.

- Menganalisis dampak penurunan kuantitas cadangan bahan bakar fosil terhadap kehidupan dan lingkungan.

- Menyebutkan karakteristik bahan bakar diesel.

- Mengidentifikasi bahan baku biosolar di Indonesia.

- Memahami konsep teknologi ramah lingkungan dalam produksi biodiesel

- Memilih bahan baku biodiesel yang ramah lingkungan.

- Menentukan karakteristik dan kualitas biodiesel ramah lingkungan. membuat biodiesel dengan bahan baku minyak jelanta.

- Melakukan uji mutu bahan bakar biodiesel yang dihasilkan pada saat eksperimen (menentukan nilai kalori, titik beku titik uap, dan massa jenis.

- Menyusun proposal projek membuat bahan bakar biodiesel dengan bahan baku alam yang terdapat di lingkungan sekitar, secara berkelompok.

- Melakukan penyelidikan untuk menemukan bahan bakar biodiesel sebagai sumber energy alternative ramah lingkungan.

- Menyusun laporan hasil kerja proyek.

- Mempublikasi hasil kerjaprojek membuat bakar bakar biodiesel dari bahan baku alami dari lingkungan sekitar lisan dan tulisan.

\section{b) Konsep-konsep yang Relevan dengan pembelajaran minyak jelanta sebagai bahan baku biodiesel.}

Berdasarkan tujuan yang telah disusun, teridentifikasi konsep-konsep relevan seperti disajikan pada GAMBAR 1.

Berisi tentang enam permasalahan seperti disampaikan pada pendahuluan. Pada penelitian ini dipilih biodiesel, dalam rangka mengikuti frame work UNESCO yang menjadikan biodiesel sebagai materi yang diintegrasikan di dalam pembelajaran sains. UNESCO has taken a special interest in the introduction of biodiesel topics in education within the framework of linking techonology to science education (UNESCO, 1988). Pemilihan materi ini juga dengan pertimbangan bahwa hasilnya tidak hanya menyelesaikan krisis energy, sekaligus juga mengatasi masalah polusi udara, seperti disampaikan oleh Chinnammai (2014), Since non-conventional energy sources provide environmentfriendly, non-polluting energy, they help keep the atmosphere and environment clean and safe.

\section{c) Minyak jelanta sebagai salah satu bahan baku biodiesel}

Dipilih dengan berbagai pertimbangan, antara lain pendapat Canakci (2001), "In general, pure refined vegetable oils are used as feedstock for biodiesel production; however, their price highly increases a biodiesel production cost. Alternatively, use of waste cooking oil with a lower cost seems to be an attractive option." Pemilihan katalis basa di dalam proses pembuatan dengan mempertimbangkan beberapa pendapat ahli berikut: the solid base catalystis active in the transesterification at the temperature around the methanol boiling point (Lopez 2007). Similar to 
their homogeneous counterparts, solid basic catalysts are more active than solid acid catalysts (Kouzu 2011). Oxides of group 2 metals are basic and have limited solubility in polar media. These metal oxides, particularly $\mathrm{CaO}$ and $\mathrm{MgO}$ are cheap and readily available, so if found to be active and stable, would be desirable catalysts for industrial biodiesel production. CaO is widely used as a solid basic catalyst possesses and has many advantages such as long catalyst lifetimes, higher activity, lower solubility in methanol and requires only moderate reaction conditions. The reaction rate, however, was slow in producing biodiesel (Liu 2008).

\section{Pengembangan Kurikulum Lingkungan Tersembunyi dalam Pembelajaran Fisika SMA}

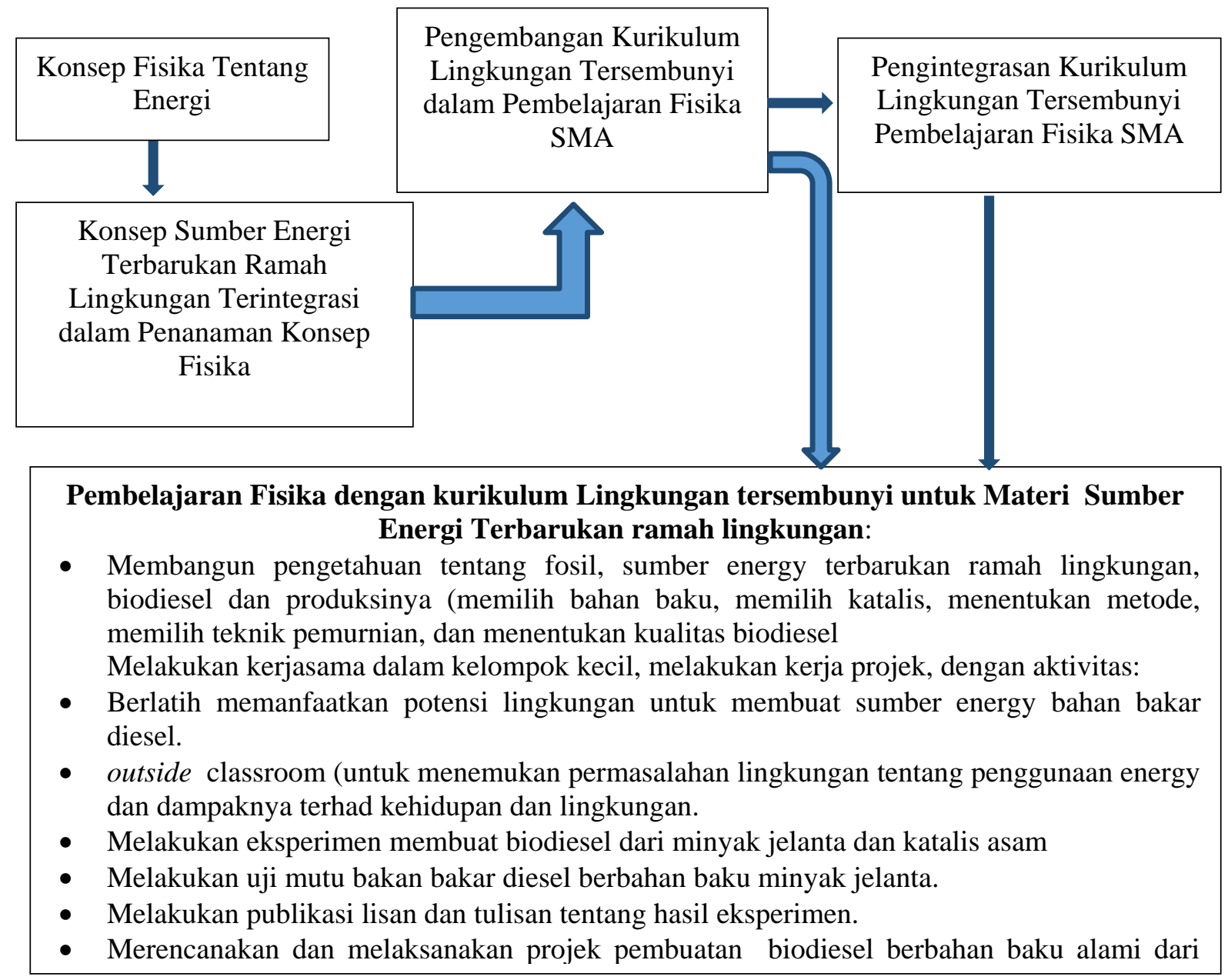

GAMBAR 1. Konsep-konsep yang Relevan dengan pembelajaran minyak jelanta sebagai bahan baku biodiesel.

d) Model, metode, dan pendekatan pembelajaran mengacu pada karakter pembelajaran fisika dan pendidikan lingkungan

Mengacu pada karakter pendidikan lingkungan yang bersifat utuh dan menyeluruh, serta terintegrasi, maka dipilih model pembelajaran Problem Based Learning, Project Based Learning, dan Cooperative Learning dengan pendekatan saintifik dan kontekstual. 


\section{e) Penilaian mengacu pada kompetensi dasar dan tujuan pendidikan lingkungan.}

Mengingat pendidikan lingkungan menyangkut semua aspek peserta didik, maka penilaian yang digunakan menerapkan penilaian otentik, yang menilai aspek pengetahuan, sikap, dan keterampilan. Instrumen terdiri dari tes, pedoman observasi, tes unjuk kerja, serta penilaian berbasis projek.

\section{Validasi dan Ujicoba}

Validasi terhadap kurikulum yang telah dikembangkan dilakukan oleh ahli pendidikan lingkungan di lingkungan UNJ, yang menyatakan bahwa kurikulum hasil pengembangan layak digunakan sebagai hidden curriculum lingkungan yang terintegrasi dalam pembelajaran fisika SMA. Ujicoba hasil pengembangan dilakukan di salah satu SMA Negeri di Jakarta Pusat yang memberikan informasi bahwa, materi kurikulum hasil pengembangan merupakan materi pengayaan dalam pembelajaran fisika SMA Kelas XII. Model pembelajaran yang tepat adalah Problem Based Learning dan Projek Based Learning dengan pendekatan saintifik dan pembelajaran kontekstual. Peserta didik merespon dengan sangat baik pembelajaran yang dilakukan, yang terlihat dari kesan mereka yang mengatakan bahwa pembelajaran menjadi sangat menyenangkan dan terasa lebih bermanfaat.

\section{KESIMPULAN}

Kurikulum tersembunyi lingkungan di dalam materi energi alternatif dirumuskan berdasarkan kompetensi dasar dalam pembelajaran fisika yang dicapai dengan pendekan konsep pendidikan lingkungan. Untuk memenuhi hal tersebut silabus pembelajaran harus berisi tujuan, materi ajar, teknologi pengolahan, uji kualitas, model dan pendekatan pembelajaran, penilaian, ujicoba, dan sosialisasi. Hasil ujicoba menunjukan bahwa siswa SMA merasa pembelajaran fisika lebih bermakna.

\section{DAFTAR PUSTAKA}

http://timpakul.web.id/enam-masalah-lingkungan-hidup.html, 9 Agustus 2009.

http://www.kapanlagi.com/h/0000149403.html, Linkungan Hidup, Kerusakan Lingkungan, Pengertian, Kerusakan Lingkungan dan Pelestarian., 09 Mei 2009.

http://timpakul.web.id/plh-4.html, Pendidikan Lingkungan Hidup: Bukan untuk Pembebanan Baru Bagi Siswa, 15 Desember 2005.

Salinan Lampiran Permendikbud No. 69 Tahun 2013 Tentang Kurikulum SMA/MA.

Matarasso, M and Dung, N. V, Environmental Education Trainer'sGuide for Nature Conservation, 2002.

United Nation Educational Scientific and Cultural Organization,1988.

Chinnammai, Srinivasan, A Study on Energy Crisis and Social Benefit of Solar Energy International Journal of Environmental Science and Development, Vol. 5, No. 4, August 2014, p. 404-411.

Canakci M, Gerpen JV. Trans ASAE, 44, 1429, 2001.

Lopez DE, Goodwin JRJG, Bruce DA, J Catal, 245, 2007.

Kouzu M, Hidaka J-S. Fuel ,90, 2011.

Liu X, He H, Wang Y, Zhu S, Fuel 87,216, 2008. 
